\title{
WEED PROBLEMS IN SOUTH CANTERBURY
}

\author{
By J. L. SYMONS, Department of Agriculture, Waimate
}

BeFore discussing the weed problems of South Canterbury, I would first like to give you a very brief outline of the topography, the general climate conditions, and the various types of farming which are practised in the respective areas. This will, I feel, give those of you who do not come from the South Island or do not have a thorough understanding of arable farming a better appreciation of our problems.

South Canterbury is comprised of four counties, Geraldine, Levels, Mackenzie, and Waimate. It embraces all the land between the Waitaki River in the south and the Rangitata River in the north, and from the sea back to the Southern Alps. It covers in all 2,800,000 acres or approximately one fifteenth of the total area of New Zealand.

Along the coast we have a narrow strip of land, varying in width from 10 to 20 miles, which is comprised of rich alluvial flats and downlands with comparatively small areas of light land at the north and south boundaries. This land is devoted to semi-intensive or intensive arable farming, and it is here that we encounter our greatest weed problems. The rainfall varies between $20 \mathrm{in}$. and $25 \mathrm{in}$. per annum, the greatest precipitation tending to be in the spring and autumn. The summers are normally hot and dry.

Further inland, and stretching the whole length of South Canterbury, are the foothills, or what is commonly termed our browntop or marginal country. Here the rainfall is between $30 \mathrm{in}$. and 40in. In the past it was regarded as store sheep country only and was the bane of bankers and firms who invested capital there. Today, thanks to lime, better pasture species, and good farm management this country is, if the prices which are being paid for it are any indication, highly desirable. When improved, it is capable of heavy stocking with sheep and cattle, and in some cases, of fattening lambs. Forage crops are of prime importance, and it is with the growing of them that we encounter weed problems. On the unploughable land we also have some weed problems.

Further inland we have our tussock ranges and the famed Mackenzit country. Very little cultivation or cropping is carried out on this comparatively arid area, and extensive grazing of sheep is the main farming activity. Nevertheless, they do have one major weed problem in certain areas which could cause great concern in the future.

I will give you a brief outline of these weeds which do at times prove a problem to farmers on the various classes of land, and the methods commonly employed to combat them. In discussion on control measures, emphasis has been placed on cultivation and sound farming practices, as they are the methods commonly used by farmers because they have proved to be fairly successful. It is possible that in the future when suitable chemicals become available their use may partially replace some of these common practices, but until such time as experimental work and farmers themselves have proved conclusively that they are effective under our climatic conditions and farming systems full use will not be made of them. It must be remembered that thorough cultivation in conjunction with a fallow is an integral part of our farming economy. It serves a dual purpose in that it not only allows adequate moisture to be conserved, which is so necessary for the growing of high-yielding crops during our dry summers, but also enables the many weeds which germinate to be killed. 
WEED PROBLEMS ON ARABLE LAND

Californian thistle (Cirsium arvense) is because of its widespread prevalence still possibly the worst weed we have to contend with on most classes of arable land. It can prove troublesome in all farm crops, and as yet we have not the answer to the most effective control in some of them. As far as cereal crops are concerned, we have, thanks to the scientists who gave us hormone weedkillers, been able to obtain very good control. It is standard practice today to spray cereal crops in thistle infested areas with either salts or amines of MCP or 2,4-D at rates up to $11 \mathrm{~b}$. The thistles not only can be controlled but up to 90 per cent. of them can be killed outright if spraying is carried out at the optimum stage and the crop is dense enough to ensure a good smother.

In fact, this method is often employed as a basic measure for eradicating thistles from a badly infested paddock. Thistles which are still alive after the cereal is harvested can be severely checked by deep ploughing and can be practically eradicated with intensive cultivation the following spring and summer prior to sowing in grass. If any thistles do appear in the grass the following year and it is possible that some will, they can be killed by spraying with hormones.

In potato crops spraying with the salts or amines of MCP at $3 / 4 \mathrm{lb}$. has practically replaced undercutting and hand hoeing which were generally employed in the past. Spraying is not always as effective as hand hoeing, because unless the thistles are well through the ground before the shaws cover the rows, efficient spray cover cannot be obtained. Damage to the potatoes is negligible if the spraying is carried out when top growth is not too vigorous.

It is in brassica crops, however, and especially those sown in November to December, in which we encounter our greatest problem in controlling Californian thistle. For January and February sowings the thistles can be effectively checked with deep and intensive cultivation in the fallow prior to sowing. It is not, however, possible to check the thistles to the same extent with such methods prior to early sowing, and as a result large areas of the brassica crops will often be smothered out. Spraying of the thistles in the pasture with hormone weedkillers prior to the paddock being ploughed up has not proved very successful, nor has the spraying of the thistles in the cultivated ground in November prior to sowing proved successful. On land where it is possible to grow a cereal crop out of lea we have a partial answer to our problem, but on our steeper downs this is not possible as very little wheat is grown on such areas today. We have fairly extensive areas of this class of land and farmers would welcome an effective control measure.

Local history has it that the next weed I wish to discuss Yarr or Spurrey (Spergula arvensis), was introduced into New Zealand, presumably by a Scotsman, as a sheep fattening crop. Whether this is right or wrong there is no doubt whatever that only one sowing was necessary, especially on our foothills or downland country. I am also certain that this is the worst weed farmers have to contend with in brassica crops. Where it will thrive, and we find it only too often on our foothills and downlands soil types, it will quickly choke out the brassica crop. Several methods are employed to cope with spurrey and they are reasonably successful. The first, and it has much to commend it from an economic point of view, is to reduce preparatory cultivation to a minimum so as to pointroy the crumb structure as little as possible when preparing the seedbed. To be successful it is essential that ploughing, preferably with a digger or short board type plough, be carried out early in winter. This allows for maximum breakdown of the soil with winter frosts and rain 
and leaves the soil in such a condition in spring that all that is generally required to prepare a seed-bed is a couple of discings and grub harrowings.

The second method is to ridge all root crops whenever possible on this class of country. Ridging has a number of advantages, but the most important as far as weed control is concerned is that it enables the crop to be intercultivated to control at least some of the spurrey. However, if the soil is extremely fine, and wet weather conditions prevail, sufficient yarr can often grow on the ridges to smother the crop. On some classes of foothill country, especially in the slightly drier areas, the methods just described are not always successful because the soils in these localities often tend to become excessively fine without overcultivation. Moreover, ridging is not always practicable because of the steepness of the country or because of a tendency for ridged ground to dry out very quickly in hot summer weather. In such cases, the only alternative is to prepare the seed-bed some time prior to the sowing of the crop in an attempt to germinate and destroy as much of the spurrey as possible before sowing This method proves quite successful when favourable weather conditions are encountered prior to and after sowing.

As yet chemicals as a means of control have not been used to any extent by farmers. Some experimental work with TCA as a preemergence treatment was carried out last season, but the results were nothing to enthuse over.

Fat-hen (Chenopodium spp.) is another weed which can prove extremely troublesome in brassica crops, especially rape, on some of our better classes of land. At present we have no control which is 100 per cent. effective. In paddocks which are known to be infested with fat-hen many farmers do take the precaution of trying to germinate and destroy as much of the fat-hen as possible prior to sowing. This practice is as much of the fat-hen as possible prior to germinate the majority of the weed seeds in the top 2in. of soil, but only too often we do not get it until the crop is sown. Away will come the fat-hen, and unless intercultivation of the crop is possible, it will smother the crop.

I have no knowledge of any work being carried out with chemicals as a means of controlling fat-hen. Their use as a pre-emergence spray does seem to offer the only possibilities for future experimentation.

Now we have a number of other weeds which occur only in isolated areas and whose control can often prove a problem. Some can be classed only as a nuisance in the crops in which they occur, but I still think they are worth mentioning.

Wild oats (Arvena fatua) still shows up in occasional autumn and spring sown cereal crops, but not to the extent that it did when more intensive cropping programmes were the order of the day. With a severe infestation the ultimate yield of any cereal crop can be considerably reduced and it can prevent the seed from being used for seed purposes. Little can be done about wild oats when it shows up in a crop until harvesting is completed.

The main aim is to destroy all the seeds which have fallen to the ground, so that they cannot infest future crops. This is usually done by sowing a greenfeed crop immediately after the cereal is harvested and following it with either a fallow or forage crop in spring. The spraying of badly infested crops with MH to destroy the germination of the oats is recommended by overseas authorities, but I do not think this is warranted under the cropping programmes generally practised today.

Ox-eye daisy (Chrysanthemum leucanthemum) often proves very troublesome in forage or cereal crops in the Willowbridge area. It thrives in those crops in which there has been a poor strike, and besides proving a nuisance at harvest, it is a prolific seeder. It can be controlled to a 
certain extent in the seedling stage by harrowing or rolling in spring, or with the salts or amines of MCP or 2,4-D, but the main aim of farmers is to ensure a good strike with the cereal crop by sowing when farmers ditions are such that a good strike is ensured. In forage crops, hand hoeing and intercultivation are the only possible control at present.

Fumitory (Fumaria muralis) often proves a problem in brassica or cereal crops in isolated areas. With the exception of intercultivation, no other methods have been employed in brassica crops to try and control the weed. In cereal crops it can be controlled in the seedling stage with the salts and amines of MCP.

Wild turnip (Brassica campestris) is fairly common in some localities. It can be effectively controlled with the salts and amines of MCP or 2,4-D in cereal crops. In forage crops, fallowing prior to sowing and intercultivation of the crops are the usual methods of control.

Cornbind (Polygonum convolvulus) and tares (Vicia sativa) often prove a nuisance in cereal crops at harvest if allowed to grow unchecked. Both can be checked in the seedling stage with the salts and amines of MCP or 2,4-D, but cornbind will of ten recover. Polyethylene glycol ester of 2,4-D is known to be an effective treatment, but very little spraying of cereals with this hormone has yet been carried out. Grazing in spring followed by harrowing and rolling will effectively destroy many of the seedlings and give some measure of control.

\section{WEEDS OF PASTURES}

In various localities throughout South Canterbury we have a number of weed grasses in pastures whose control does not create any special problems as they can generally be kept in check with sound farm management practices. These include hairgrass ( $V$ ulpia dertonensis), sweet vernal (Anthoxanthum odonatum), browntop (Agrostis tenuis), creeping fog (Holcus mollis), Yorkshire fog (Holcus lanatus), and goosegrass (Bromus mollis). Some, however, do prove a problem in lucerne and I will deal with them later.

In barley grass (Hordeum murinum) we have one grass weed which unfortunately, cannot altogether be controlled by good farm management Now there is no doubt that this insidious weed is spreading and it is causing many farmers on our better-class land some concern. Its spread has probably been accentuated by the build up in fertility due to decreased cropping, increased topdressing, and as a result pastures with a longer life and of higher stock carrying capacity. The major difficulty we have to contend with is controlling barley grass in nucleus areas which are usually situated on sheep camps or along fencelines, and thus prevent its spreading into adjacent pastures. Experimental work has shown us that barley grass in the seedling stage can be effectively killed with TCA at rates from 101b. to 201b. The main problem, however, is then to establish and hold a dense sward of desirable grass species on the areas which have been treated and thus prevent further ingress of the barley grass. This is not as easy as it sounds, because sheep camps are usually situated on the warmest and driest parts of the paddock. Therefore it does seem to me that the problem is one involving grass establishment and maintenance rather than one of straight out weed control.

Browntop and Yorkshire fog are two grass species which often prove very troublesome in lucerne stands, the former in irrigated stands and the latter in non-irrigated areas. Both species will, if allowed to grow unchecked, take complete control. To date control measures have been limited to grubbing with lucerne points or with a Bevan-type harrow in late autumn or winter. The harrow has proved superior to the grubber 
in controlling Yorkshire fog, but neither has proved very successful in controlling Yorkshire fog, but neither has proved However, it does seem that the problem could be largely overcome by ensuring that the soil was relatively free of such weeds prior to sowing or by the sowing of desirable grass species such as cocksfoot and timothy with the lucerne.

Now there are a number of other weeds whose control is often a problem in pastures, and the first I wish to discuss is nodding thistle (Carduns mutans). This weed can cause considerable damage to pastures (Carduns mutans). This weed if allowed to grow unchecked. It is spreading throughout South Canterbury, but it cannot altogether be classed as a ing throughout South Canterfectively controlled with salts and amines of problem, as it can be van MCP and 2,4-D at up to 11b. when in the seedling stage. Clovers in the dry spell of weather follows spraying.

Docks (Rumex spp.) are often troublesome in some of the pastures on heavy dairying land or in the paddocks on farms which are used on heavy dairying laning house cows. They are also often a problem predominanty in Montgomery or red clover seed stands and in lucerne. The control of the mature dock in pastures with polyethylene glycol ester of 2,4-D at $21 \mathrm{~b}$. per acre has not given satisfactory results. Fairly good control of seedling docks, however, has been obtained with the salts and amines of MCP. In established lucerne stands good control of docks has been obtained in experimental work with $\mathrm{MH}$ at $11 \mathrm{~b}$. and $21 \mathrm{~b}$., but it was very severe on the lucerne.

Fairly successful control of docks is secured with intensive cultivation during a fallow in dry summers, provided the soil does not become excessively fine.

In such cases, the greatest difficulty is experienced in keeping the roots on the surface where they can be dried out and killed. When roots on the surface wise the rotary hoe will often give good results, such a situation does arise the rotary hoe we surface, where they can be effectively dealt with.

\section{WEEDS OF FOOTHILLS AND HIGH TUSSOCK COUNTRY}

By far the worst weed many farmers on the foothills have to contend with is gorse (Ulex europaeus). Allowed to grow practically unchecked during the depression of the thirties and, later, World War II, checked dus of ploughable and unploughable it spread rapidly over thousands of acres of ploughable and unploughable land. Due to economic conditions and the lack of suitable machinery no real attempt to reclaim this land was made until after the war. Since then rapid strides have been made and much of the ploughable land has now been cleared. The use of the crawler tractor in conjunction with the bulldozer, the giant discs, and the swamp plough have proved invaluable for the initial clearing work, while spraying of the regrowths
with $2,4,5-T$ has done just as remarkable a job in preventing a reinfestation.

On the unploughable country burning is still the traditional control. A number of farmers have in recent years followed up the burning with A number of farmers have in recent yeaths with 2,4,5-T with fair results. aerial or ground spraying of the I think, warranted, because much of this country, if cleared and oversown with clovers and topdressed with phoscountry, if cleared and overs numbers of phates and possibly lime, is capable of carrying fairly high numberserisheep and cattle to the acre. However, I do think that further experimentation is required before we can definitely say that we have the answer to what is the most efficient and economic technique to employ on this type of land. 
Matagouri (Discaria toumatou) is another plant which may prove difficult to control in the future. Firing of the surrounding tussock is the only known method of keeping the plant in check. However, with the restriction of burning in some areas and the inability to get a good burn on country which has been topdressed and oversown, matagouri could easily get out of control in certain areas, unless some other effective means of controlling it is found.

Sweet briar (Rosa eglanteria) is spreading rapidly through some of our tussock country now that the rabbit population has been greatly decreased through the excellent work of the Rabbit Boards. I consider that this weed is the major menace on this class of country and if allowed to grow unchecked, it could in time possibly take charge of large areas. As yet I know of no practical means of control, but it is hoped that the extensive experimental work which is being carried out at present will throw some light on the matter.

In conclusion let me tell you briefly just how serious or otherwise I consider weeds generally to be on the various phases of farming in South Canterbury. First, with regard to pastures, I do not think we have any widespread weed problems which could be classed as really serious. Nor, with the possible exception of Californian thistles, which can be controlled extremely well with hormone weedkillers, have we any serious weeds in our cereals or other cash crops. However, in the brassicas, which are more extensively grown than any other crop, we do have three main weeds which can prove serious problems at times in the localities in which they occur. In the foothills and tussock country the weeds I have mentioned are strictly speaking only problems as yet in very limited areas.

As far as weed control is concerned we still have a number of problems for which we require an answer. Good husbandry can give us some measure of control in the meantime, but it is, I think, towards weedkillers that we must look for the complete answer to our problems in
the future.

\section{DISCUSSION}

Q. What is the efficiency of the polyethylene glycol ester of 2,4-D on docks in this district?

A.- Results obtained have been from farming experience and these would indicate only approximately 50 per cent. control.

Q.-As there appear to be no serious weed problems in South Canterbury, is this because of good husbandry or is it that chemical methods have been fitted in already and overcome the problems?

A.-Cropping is not so extensive as in years past. It is my opinion that it is not the result of chemical weedkillers being used as yet. 